\title{
Modelli interpretativi a servizio dell'arte: la porta del paradiso di Lorenzo Ghiberti
}

\author{
Alessandro Merlo \\ Matteo Bartoli
}

Abstract

La porta del Paradiso del Battistero di Firenze [I], realizzata da Lorenzo Ghiberti tra il I 427 e il I452, è riconosciuta dalla critica artistica come una delle opere che segnano il passaggio dall'arte medievale a quella rinascimentale [Krautheimer 1970, pp. 298-305]. I bassorilievi delle dieci formelle bronzee palesano, sia dal punto di vista iconografico che da quello tecnico, una marcata differenza rispetto alla produzione precedente, anche dello stesso maestro. L'elemento che permane nel mutamento è la funzione narrativa dell'arte; in quella cristiana il linguaggio figurativo continua infatti a svolgere un'importante funzione catechetica [Ciardi Duprè Dal Poggetto 1978, pp. 330-332]. Per poter comprendere pienamente il significato del testo trasfigurato è necessario, oggi come allora, possedere dei codici di lettura; nel corso dei secoli tali codici sono andati progressivamente persi, rendendo in parte 'mute' le scene raffigurate nella porta.

II contributo intende illustrare un'esperienza condotta da un gruppo di ricercatori del CHMLab del DIDA (UNIFI) in collaborazione con il Museo dell'Opera di Santa Maria del Fiore nell'ambito delle digital Humanities, finalizzata all'analisi e alla restituzione, mediante modellazione e animazione 3D, degli avvenimenti che hanno luogo all'interno del 'paesaggio delle formelle', consentendone una rinnovata e più immediata lettura. (A.M.).

Parole chiave

patrimonio culturale, modellazione 3D, digital humanities, Porta del Paradiso, Ghibertiana.

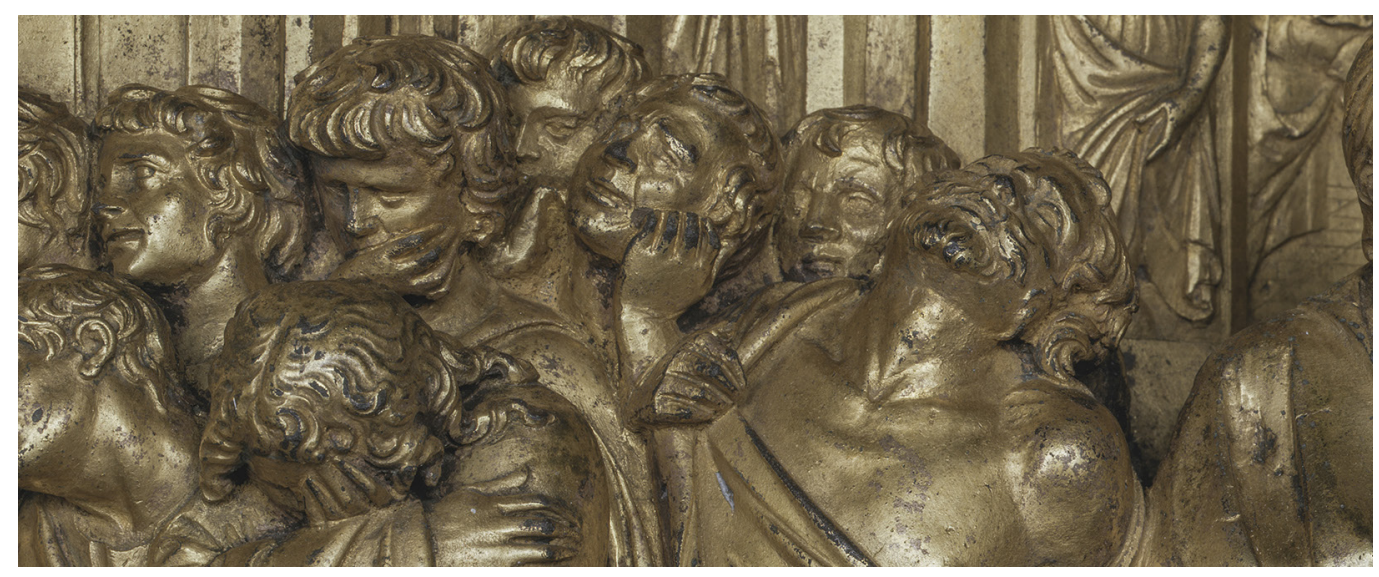


Le formelle della Porta del Paradiso

Delle tre porte del Battistero di Firenze due vennero commissionate a Ghiberti: la seconda (|403-|424) con le Storie della vita di Cristo, e la terza (|425- |452) nella quale sono raffigurate le Storie del Vecchio Testamento (fig. I).

Gli esiti del noto concorso del I40 I, che vide prevalere un giovanissimo Ghiberti su Filippo Brunelleschi e che valsero al maestro l'affidamento della seconda porta, misero in evidenza non solo le sue straordinarie doti di scultore e cesellatore, ma soprattutto l'impiego di una nuova tecnica di fusione che consentiva la realizzazione di superfici sottili e più facilmente modellabili [Siano 20 I5, pp. 67-80]. Con la terza porta, rompendo con una tradizione millenaria che aveva visto le porte bronzee decorate con una grande quantità di formelle singole (28 nel caso della prima porta di Andrea Pisano e della seconda), l'autore descrive le storie comprese nei primi libri della Bibbia in sole dieci formelle [2], abbandonando nel contempo i quadrilobi e utilizzando al loro posto il formato quadrato [Giusti 20I2, p. 68].

Le scene presenti in ciascuna formella (talvolta fino a nove eventi raccolti nella medesima opera) vengono raffigurate su una pluralità di piani; a differenza di quello che ci si potrebbe aspettare da un'applicazione rigorosa della prospettiva, che il maestro conosceva bene, in base alla quale le figure più distanti avrebbero dovuto essere più piccole e in bassorilievo, Ghiberti enfatizza le sue scene facendo aggettare, talvolta fino quasi al tutto tondo, non solo gli elementi in primo piano, ma talvolta anche a quelli sullo fondo, distorcendo e scorciando magistralmente le figure stesse (fig. 2). (A.M).



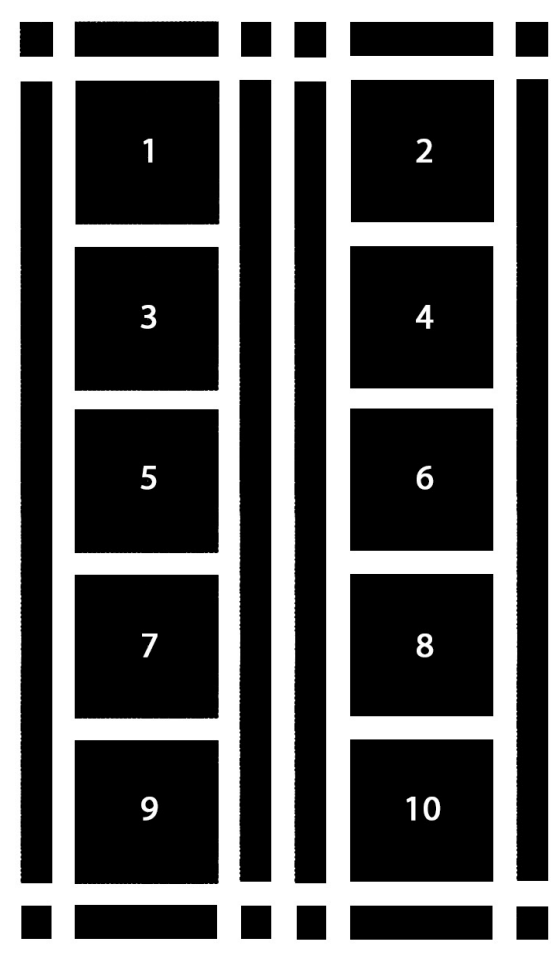

Storie di:

1. Adamo ed Eva, 2. Caino e Abele, 3. Noè, 4. Abramo, 5. Giacobbe ed Esaù, 6. Giuseppe, 7. Mosè,

8. Giosuè, 9. Davide, 10. Salomone. 


\section{II progetto ‘Ghibertiana'}

L'esperienza descritta nel presente contributo si inserisce all'interno di un progetto complesso, interdisciplinare e multiscalare, denominato 'Ghibertiana' [3], finalizzato alla valorizzazione del legame che vi è tra il patrimonio culturale della bassa Valdsieve e le opere di Lorenzo Ghiberti (Pelago 1378 - Firenze I455), che in questa terra ebbe i natali e investì parte delle sue fortune [4].

Il progetto prevede la realizzazione del Centro di Documentazione su Lorenzo Ghiberti - nel quale saranno raccolte in forma dematerializzata tutte le informazioni relative all'artista e alle sue opere, consentendo agli studiosi di disporre di un luogo dedicato per le ricerche sul maestro - e del 'Centro di Interpretazione sulla bassa Valdisieve' - dove sarà possibile acquisire le chiavi di lettura per decodificare nella corretta prospettiva storica i luoghi di maggior interesse di questa porzione di territorio (Le terre del Ghiberti) [5]. Utilizzando la scontata, ma quanto mai efficace, metafora della 'porta', quest'ultimo Centro consentirà, una volta varcata la sua soglia, di cogliere quegli elementi presenti nel primo Quattrocento nel paesaggio della bassa Valdisieve che Ghiberti ha raffigurato sovente nelle sue opere e che ancora oggi permangono come segno indelebile del lavoro dell'uomo [6].

Nella sala 5, dedicata alla porta del Paradiso, saranno ospitate le stampe in 3D delle dieci formelle (ciascuna della dimensione di $80 \times 80 \mathrm{~cm}$ [Masotti 20I5, p. 213] realizzate dal maestro per il Battistero di San Giovanni in Firenze, riprodotte in materiale plastico in scala I:I e prive del dato cromatico. Le copie, poste ad una altezza tale da consentire ai visitatori di compiere un'inedita esperienza tattile, permetteranno anche agli ipovedenti, di apprezzare i numerosi piani in cui Ghiberti ha raffigurato architetture, paesaggi, animali e personaggi descritti nelle storie dei profeti.

Ogni formella, inoltre, funzionerà da target, consentendo di attivare su un device (tablet in uso gratuito ai visitatori per il tempo della visita oppure dispositivi mobili personali) un'animazione $3 \mathrm{D}$ che proietterà il fruitore all'interno dello spazio rappresentato dal maestro. All'immagine inquadrata dalla telecamera si sostituiranno progressivamente i frames con i render del modello 3D della formella dotato del colore apparente. Le sequenze video, realizzate ad hoc al fine di inquadrare unicamente le parti delle mesh che è stato possibile generare a partire dalle raffigurazioni originali, consentiranno di descrivere nella giusta sequenza temporale i molteplici eventi che Ghiberti ha ritratto all'interno di una medesima formella, fornendo nel contempo una spiegazione, attraverso una voce narrante, delle vicende stesse in riferimento al testo biblico. (A.M.).

Fig. 2. Lorenzo Ghiberti, Porta del Paradiso, Storie di Giuseppe (particolare con gli Egiziani che caricano il grano).
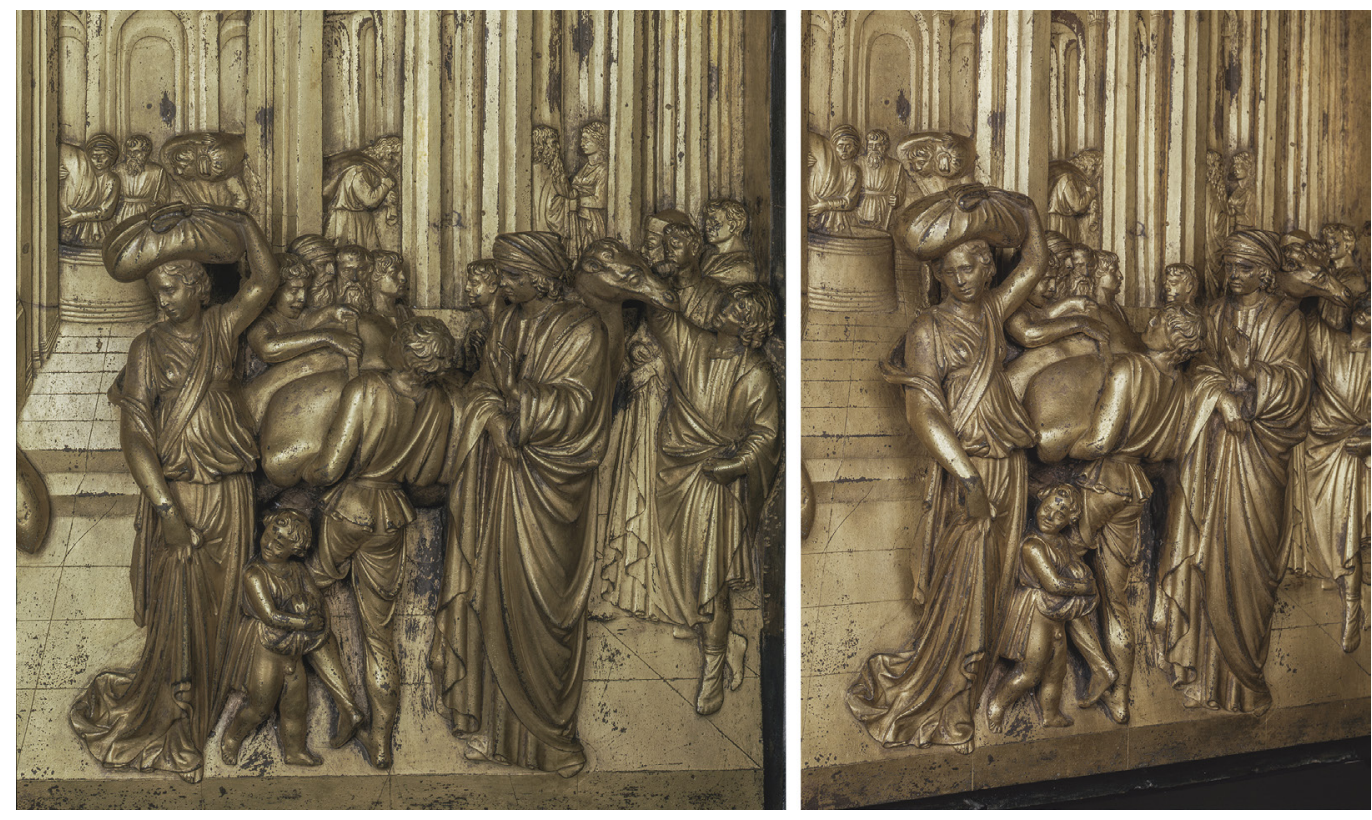


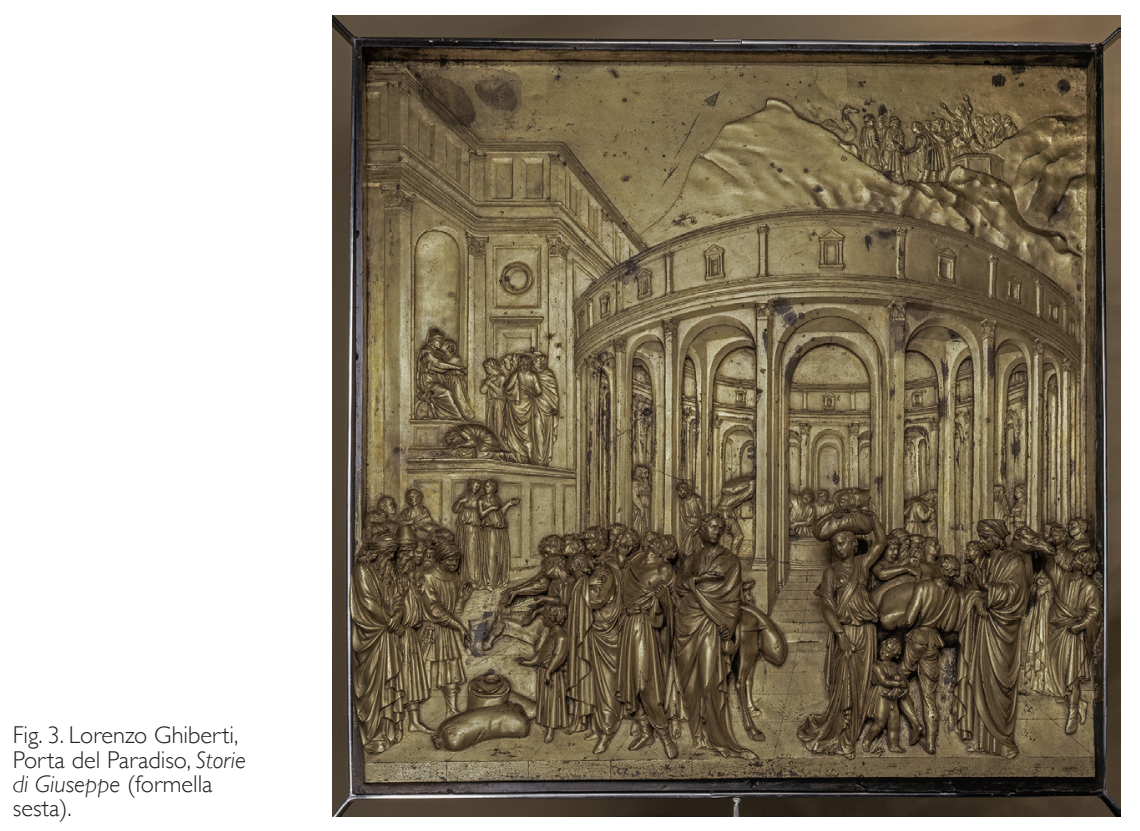

\section{La formella con le Storie di Giuseppe}

Al fine di illustrare in modo circostanziato le operazioni realizzate sulle singole formelle viene qui presa in esame l'opera (sesto quadro, fig. 3) con Le storie di Giuseppe e i suoi fratelli alla quale si riferiscono anche le immagini del testo.

II maestro apre il racconto visivo in alto a destra con l'illustrazione del testo di Genesi 37,28: "Passarono alcuni mercanti madianiti; essi (i fratelli di Giuseppe) tirarono su ed estrassero Giuseppe dalla cisterna e per venti sicli d'argento vendettero Giuseppe agli Ismaeliti. Così Giuseppe fu condotto in Egitto". II secondo episodio illustrato in modo esplicito dal Ghiberti, nel secondo piano in basso dentro la grande struttura ad arcate, corrisponde al testo di Genesi 41,48-49: "Egli (Giuseppe) raccolse tutti i viveri dei sette anni di abbondanza che vennero nella terra d'Egitto, e ripose i viveri nelle città; in ogni città i viveri della campagna circostante. Giuseppe ammassò il grano come la sabbia del mare, in grandissima quantità, così che non se ne fece più il computo, perché era incalcolabile". II terzo passo biblico raffigurato, in primo piano in basso a destra, è Genesi 41,56-57: "La carestia imperversava su tutta la terra. Allora Giuseppe aprì tutti i depositi in cui vi era grano e lo vendette agli Egiziani. La carestia si aggravava in Egitto, ma da ogni paese venivano in Egitto per acquistare grano da Giuseppe, perché la carestia infieriva su tutta la terra". II quarto passo rappresentato, in primo piano a sinistra, è Genesi 44, I I- I3, in cui, per rispondere all'accusa del servo di Giuseppe, secondo cui in uno dei sacchi di grano che i fratelli di Giuseppe riportano in Canaan ci fosse una coppa d'argento rubato dalla casa di Giuseppe, "Ciascuno si affrettò a scaricare a terra il suo sacco e lo aprì. Quegli (il servo) li frugò cominciando dal maggiore e finendo col più piccolo, e la coppa fu trovata nel sacco di Beniamino. Allora essi (i fratelli) si stracciarono le vesti, ricaricarono il proprio asino e tornarono in città". II quinto ed ultimo passo biblico illustrato, sopra la scena del sacco di Beniamino, è Genesi 45,3 e 45, I 4, in cui Giuseppe si fa conoscere: "Giuseppe disse ai fratelli: 'Io sono Giuseppe. Ė ancora vivo mio padre?' Ma i suoi fratelli non potevano rispondergli, perché sconvolti dalla sua presenza. Allora egli si gettò al collo di suo fratello Beniamino e pianse. Anche Beniamino piangeva, stretto al suo collo". In questa formella, così come nella quinta e nella decima, i singoli episodi si svolgono prioritariamente in un contento urbano. Escludendo la prima vicenda, infatti, che ha luogo sulle creste di una collina, la seconda avviene all'interno di un edificio circolare che funge da granaio (al centro è posta la buca dei grani), la terza e la quarta accadono nella piazza antistante e l'ultima si compie su un podio, che è parte integrante di un edificio classicheggiante. Al di là delle possibili analogie con edifici che Ghiberti potrebbe avere 


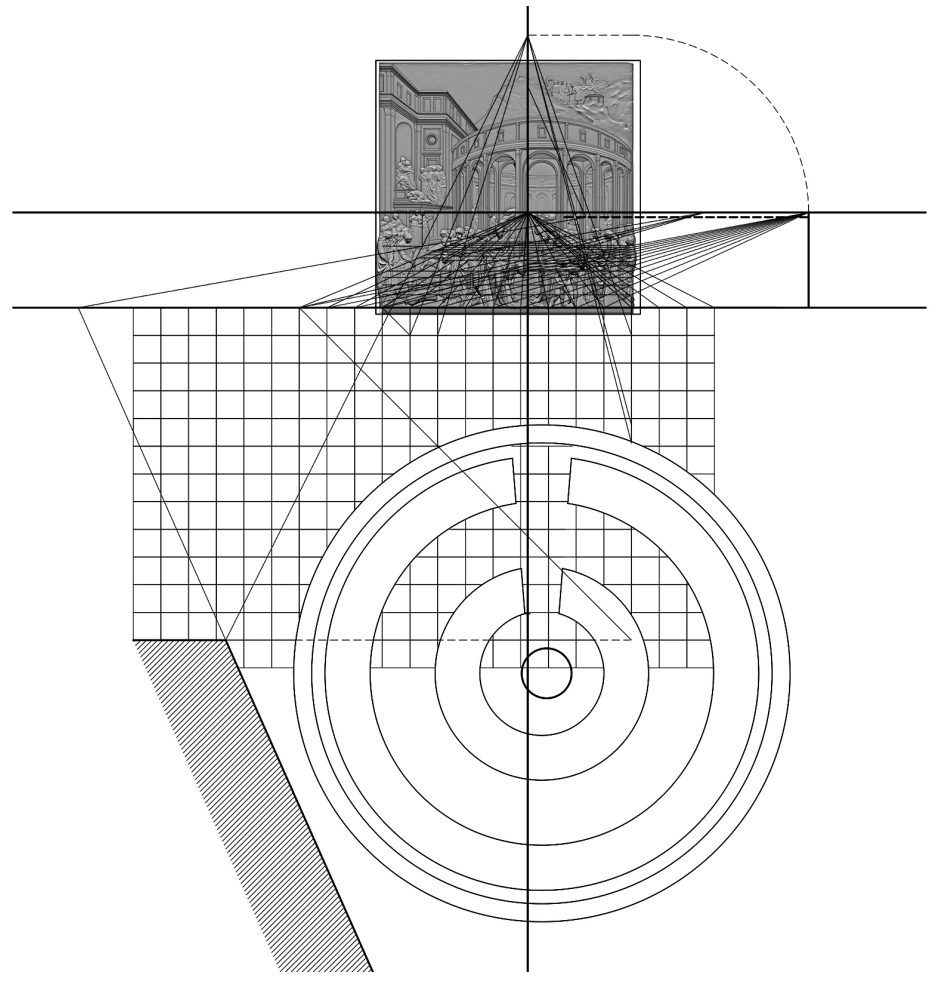

visto durante i suoi viaggi o ripreso da altre opere [Gurrieri 20।4, pp. 75-79], si tratta di architetture di fantasia funzionali al racconto, nelle quali il maestro compone in forma nuova elementi dell'antichità greco-romana [Borsi 1978, p. 464].

Le geometrie sottese negli edifici come nelle pavimentazioni consentono più facilmente, rispetto alle formelle nelle quali gli episodi si svolgono all'interno di paesaggi bucolici, di dedurre l'impianto compositivo della scena.

Ne Le storie di Giuseppe, ad esempio, una volta ottenuta l'immagine frontale della formella renderizzando il modello high-poly e ipotizzato che i piani di calpestio fossero suddivisi da maglie quadrate poste parallelamente al quadro, è stato possibile rintracciare gli elementi fondamentali della prospettiva e, successivamente, le posizioni e i rapporti reciproci tra i vari corpi di fabbrica, che sono stati modellati e riposizionati all'interno dello spazio 3D (fig. 4). L'esercizio, funzionale allo scopo del progetto, ha consentito di confermare l'uso corretto della proiezione conica da parte del maestro (quanto meno per la raffigurazione degli elementi a terra) tenuto conto anche della presenza di numerose parti aggettanti che sono state modellate in modo da assecondare la prospettiva stessa.

Le ragioni dell'arte, che sovrintendono ogni cosa, hanno poi fatto sì che Ghiberti aggiustasse intenzionalmente le forme in funzione del racconto [Degl'Innocenti 1978, pp. 127, I28]. La buca del grano, ad esempio, non è collocata al centro dell'edificio circolare, ma spostata verso sinistra in modo da non essere occultata dalle figure in primo piano; la fuga del pavimento che si dirige verso la buca è stata anch'essa dislocata per enfatizzare la vista della buca stessa; tutti gli elementi che stanno al di sopra della linea di fuga hanno il loro "fuoco" al di sopra di quest'ultima, verosimilmente per non distorcere in modo eccessivo le figure presenti nei $2 / 3$ superiori della formella. (A.M.).

\section{Operazioni di modelling e texturing}

Il gruppo di lavoro ha potuto disporre dei modelli high-poly delle formelle realizzati a seguito della documentazione morfometrica [7] delle stesse effettuata durante le operazioni di restauro [Giusti 2015, pp. 166-|75]. II modello originale con Le storie di Giuseppe, ad 


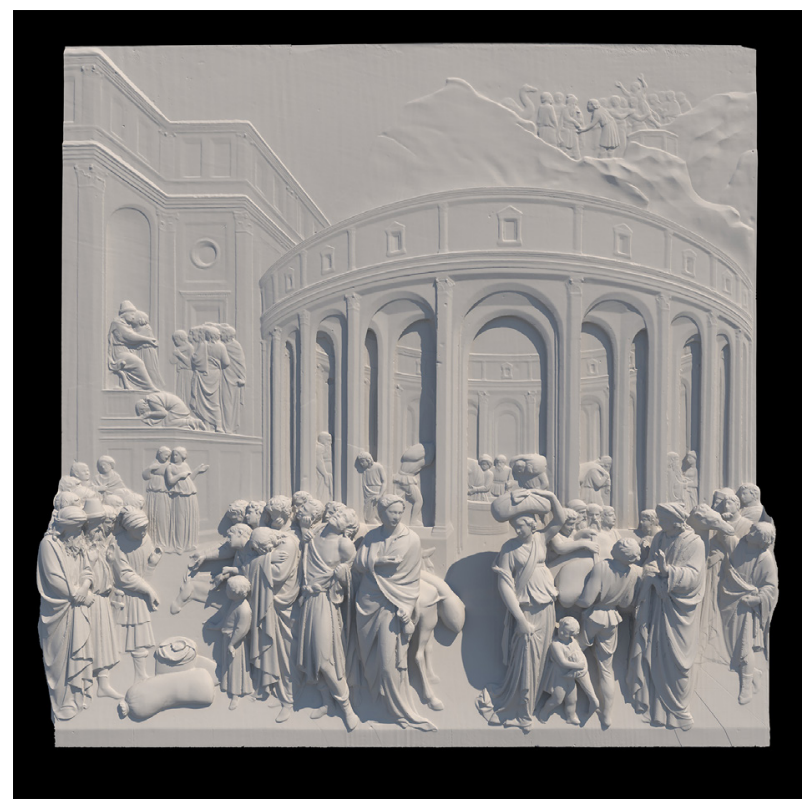

esempio, è costituito da 26.3 I2.297 poligoni con una lunghezza media del lato pari a 0,278 mm (dimensione del file I,284 Gb, fig. 5).

Per assecondare le finalità del progetto era necessario, per ciascuna formella e a partire dalla loro copia digitale, disporre dei modelli 3D sia del contesto nel quale si svolgono i singoli episodi, sia dei personaggi e degli oggetti che la popolano.

Gli elementi utili alla ricomposizione della scena tridimensionale sono stati suddivisi in funzione di due parametri distinti, uno legato al ruolo ricoperto nella narrazione degli episodi biblici, l'altro al dato spaziale di partenza (ovvero al loro aggetto).

Definiti i gruppi, ogni elemento è stato isolato dagli altri e dal fondo e sottoposto ad un primo processo di decimazione attraverso il software Geomagic (riduzione del numero di poligoni pari al 30\%) che ha consentito inoltre di generare superfici isotrope (fig. 6).

Successivamente le singole componenti sono state importate allinterno del programma Zbrush e sottoposte ad un processo semiautomatico di retopology attraverso la funzione Zremesher [8], che ha consentito sia di ridurre ulteriormente il numero dei poligoni sia di generare maglie quad-dominant, le quali forniscono in genere risultati migliori al momento di parametrizzare i modelli (fig. 7).

Allo scopo di compensare la perdita del dato geometrico e, conseguentemente, anche dei dettagli impressi dall'artista, si è deciso di fare affidamento alle mappe U,V. Per poter applicare tali mappe è stato necessario preliminarmente procedere alla parametrizzazione dei modelli high-poly che è stata realizzata mediante la funzione Autounwrap del programma Substance Painter, in grado di coniugare in modo efficace velocità di esecuzione e bontà del risultato (fig. 8) [9]. Le mappe utilizzate, oltre a quella delle normali, come l'Ambient Occlusion Map e la Curvature Map, sono state ottenute tramite il comando Bake Mesh Map dello stesso software [ I 0].

Al fine di non introdurre componenti arbitrarie è stato deciso preliminarmente di lasciare inalterate le figure e di non procedere, pertanto, alla ricostruzione delle parti mancanti.

Un atteggiamento diverso è stato assunto invece nei confronti di quelle componenti che definiscono i contesti (scene), siano esse architetture (quinto, sesto e decimo quadro) o paesaggi collinari/montani. In questo caso, infatti, la presenza di lacune avrebbe reso vano ogni tentativo di documentare gli elementi raffigurati dal maestro all'interno di uno spazio tridimensionale continuo.

Le architetture sono state ricostruite per intero mediante modellazione diretta in ambiente 3ds Max a partire dagli esiti della ricostruzione prospettica (fig. 9).

Colline e montagne $[\mathrm{II}$ ], che Ghiberti figura sotto forma di rupi rocciose più o meno digradanti, sono state realizzate attraverso un'operazione di retopology manuale, sempre 
Fig. 6. Lorenzo Ghiberti, Porta del Paradiso, Storie di Giuseppe (particolare di Gluseppe (particolare gruppo di figure)

Fig. 7. Lorenzo Ghiberti, Porta del Paradiso, Storie di Giuseppe (particolare del retopology di un gruppo di figure).
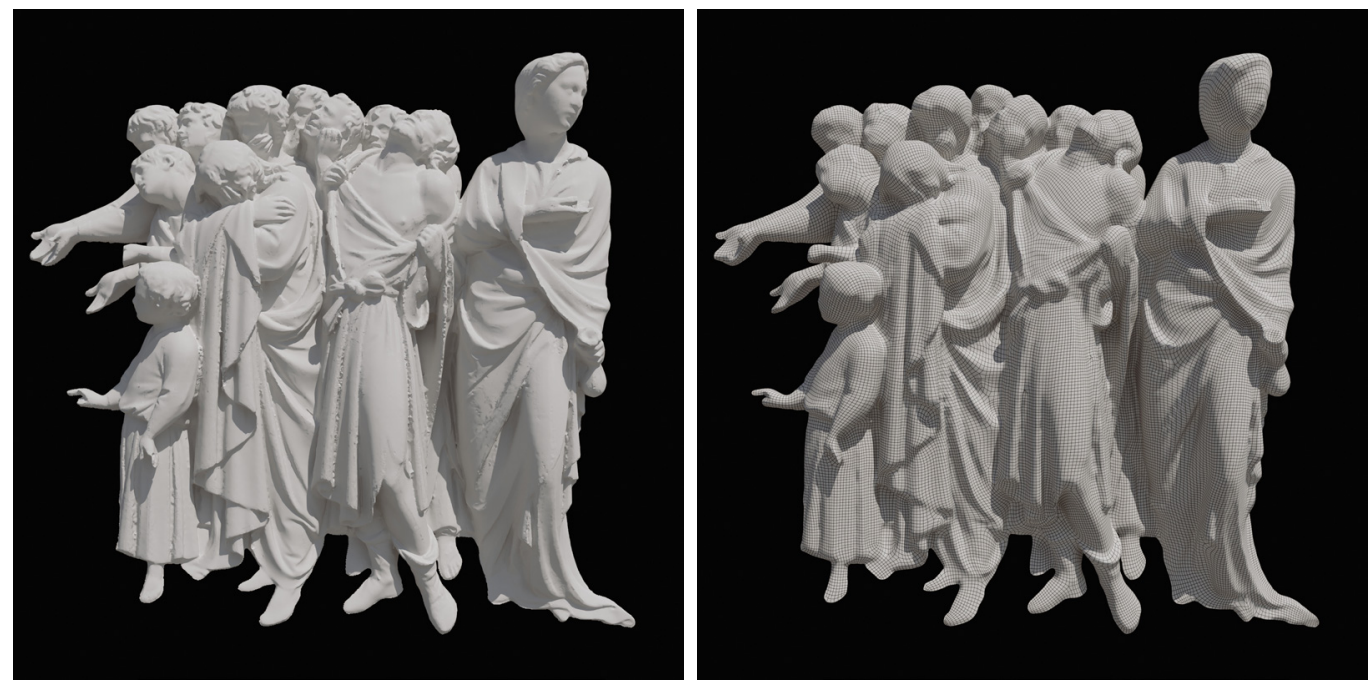

all'interno di 3ds Max, seguendo accuratamente i profili e le spigolosità, successivamente enfatizzate attraverso i 'modificatori' di displacement e turbosmooth.

Per evitare di generare, per effetto della prospettiva, ampie aree che non sono state descritte dall'artista, le montagne poste sullo sfondo sono state modellate utilizzando le stesse dimensioni che esse hanno nelle formelle; utilizzando questo artificio, infatti, è stato possibile ridurre sensibilmente le distanze tra elementi in primo piano ed elementi sullo sfondo.

In ogni formella personaggi, oggetti, piante e animali aggettano rispetto al piano al quale sono ancorati in misura diversa; alcuni sono appena incisi sulla lastra di bronzo mentre altri si avvicinano al tutto tondo. Anche in questo caso laddove è stato ritenuto opportuno fare risaltare i dettagli si è fatto ricorso nuovamente alle mappe di displacement.

Per ciò che concerne il texturing è stato deciso di impiegare le mappe procedurali. ॥ programma Substance Painter ha consentito in primo luogo di adottare un materiale, nel caso in esame un metallo, che simula la doratura a mercurio impressa sulle formelle, al quale sono state successivamente applicate delle mappe procedurali (Grunge map, Scratches map, etc.) che hanno consentito di personalizzare il materiale agendo sui molteplici parametri a disposizione. Una volta raggiunto l'effetto desiderato il programma ha permesso di esportare delle mappe 4K ad hoc per Corona Renderer (diffuse map, glossiness map, reflection map, height map, IOR map) che sono state utilizzate per texturizzare i modelli. Dato il numero elevato degli oggetti presenti in una stessa scena, la scelta di questo metodo ha consentito un più semplice e immediato controllo dei risultati ottenuti (figg. I0, I I). (M.B.).

\section{L'animazione 3D}

La scelta di lasciare inalterate le figure e, pertanto, di non procedere alla ricostruzione delle parti mancanti ha limitato drasticamente la possibilità di muovere a piacimento la telecamera all'interno dello spazio tridimensionale, vincolandola a posizioni predefinite dalle quali sarebbero stati ripresi solo gli elementi realmente modellati dall'artista e nascondendo contemporaneamente alla vista le lacune precedentemente descritte.

Sulla base dello storyboard sono state realizzate delle sequenze animate che consentono di esplorare il 'paesaggio dell'arte' raffigurato a Ghiberti.

Un efficace espediente per conferire maggiore dinamicità alle scene mantenendosi il più fedeli possibile all'opera dell'artista, oltre a quello dei piccoli movimenti impressi alle mesh attraverso tecniche di rigging, risulta essere l'animazione di parti di texture ricavate dalle fotografie ad alta definizione delle formelle. Questo espediente è risultato particolarmente utile per simulare, ad esempio, il moto dell'acqua; in questo caso all'animazione della texture è stato aggiunto un modificatore noise, anch'esso animato, in modo da simulare lo scorrere di un torrente. (M.B.) 
Fig. 8. Lorenzo Ghiberti, Porta del Paradiso, Storie di Giuseppe (particolare della parametrizzazion di un gruppo di figure)

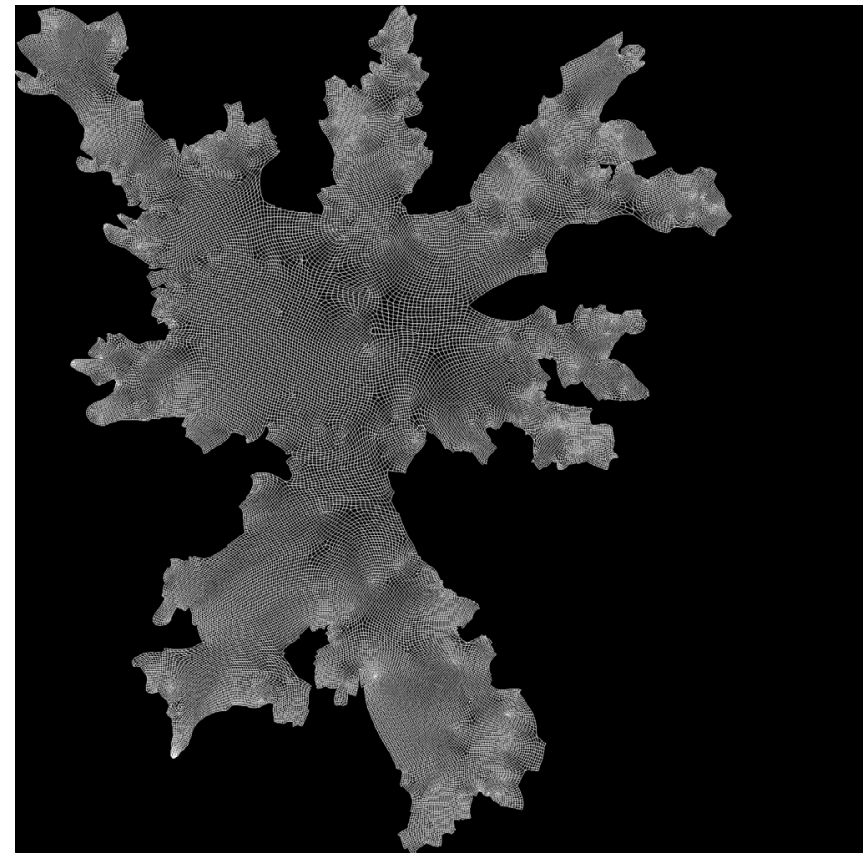

\section{Conclusioni}

Le odierne tecnologie digitali consentono di fruire del patrimonio culturale in forme nuove e più vicine a quelle che sono le aspettative non solo del pubblico dei non specialisti, ma sempre più anche di quello degli addetti ai lavori. Superato il preconcetto iniziale, che per molti anni e in parte ancora oggi ha fatto sì che non venisse riconosciuto il valore scientifico di questi prodotti, sono molte le iniziative in tutti gli ambiti della ricerca che spingono verso l'utilizzo della realtà virtuale e delle sue molteplici declinazioni (AR, IR e MR) e utilizzi (dall'animazione 3D alle applicazioni multimediali). Le indicazioni espresse nelle direttive ministeriali per i musei 4.0 [12], ad esempio, confermano la direzione intrapresa. Nell'ambito umanistico le ditigital humanities sono ormai una realtà affermata e un ambito di ricerca in continua evoluzione; come nel caso in esame le tecnologie digitali da una parte consentono di aprire nuovi orizzonti interpretativi, dall'altro permettono di veicolare con profitto i risultati che ne scaturiscono. (A.M.).
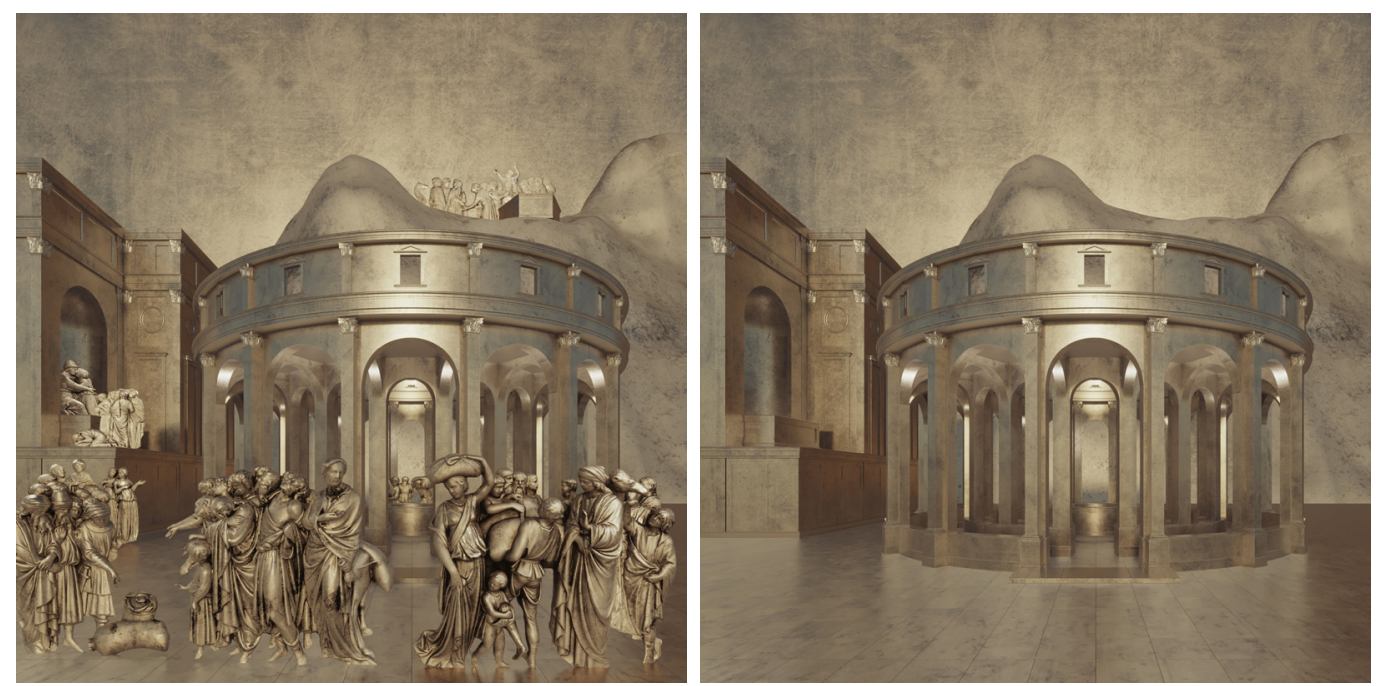

Fig. 9. Render della scena con le sole architetture della formella con le

Fig. 10. Render della scena della formella con le Storie di Giuseppe. 
Fig. II. Render della scena della formella con le Storie di Giuseppe (particolare)

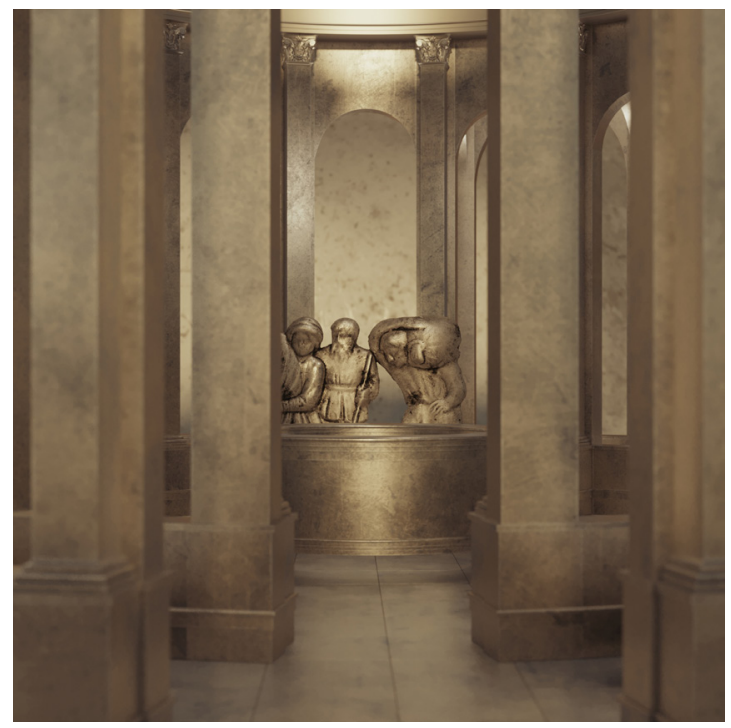

\section{Ringraziamenti}

Si ringraziano il prof. Filippo Fantini per aver contribuito alla definizione della pipeline di lavoro per la realizzazione dei modelli 3D, mons. Timothy Verdon (direttore) e il dott. Giovanni Serafini dell'Opera di Santa Maria del Fiore per le analisi dei testi sacri e la stesura dello storyboard e, infine, la prof. Giuseppina Carla Romby per la lettura storico-figurativa delle architetture rappresentate dal Ghiberti.

\section{Note}

[I] "Il Battistero di San Giovanni di Firenze rappresenta uno dei monumenti simbolo della città e della sua identità storica e religiosa... patrocinato dalla potente e ricca Arte di Calimala, costituita da mercanti che agivano a livello internazionale. Tutti questi motivi ci rendono chiara la ragione per cui il Battistero fiorentino ebbe, tra il Medioevo e il Rinascimento, alcune delle commissioni artistiche più importanti della città" [Ciatti 20 I5, p. I3].

[2] Le storie raffigurate nelle 10 formelle riguardano: Adamo ed Eva, Caino e Abele, Noè, Abramo, Giacobbe ed Esau, Giuseppe, Mosè, Giosuè, Davide e, infine, Salomone.

[3] Per maggiori informazioni sul Progetto cfr. www.ghibertiana.it (consultato il 5 maggio 202I).

[4] 'Ghibertiana' è un progetto universitario nato dalla collaborazione tra il Dipartimento di Architettura (DIDA) e il Dipartimento di Storia, Archeologia, Geografia, Arte, Spettacolo (SAGAS) di UNIFI. Coordinano il Progetto Alessandro Merlo e Giuseppina Carla Romby; il Comitato Scientifico è formato, oltre che da questi ultimi, da Paolo Clini e dai responsabili di ciascuna delle sale espositive (Dora Liscia Bemporad, Paolo Nanni, Francesco Salvestini, Guido Vannini con Chiara Molducci).

[5] II Centro di Interpretazione del Territorio della bassa Valdisieve e il Centro di Documentazione su Lorenzo Ghiberti saranno ospitati nel trecentesco palazzo comunale nel castello di Pelago. Questo edificio storico di proprietà dell'omonimo Comune è stato restaurato nel 2017 con finalità museali e, dal 2018 è stato assegnato al Progetto.

[6] Negli ultimi tre anni sono stati formalizzati degli accordi con l'Opera di Santa Maria del Fiore, con l'Opificio delle Pietre Dure, con l'Accademia dei Georgofili, con II Museo dell'Opera del Duomo e, più recentemente, con le Gallerie degli Uffizi. Per quanto concerne gli accordi con gli enti territoriali, il Progetto coinvolge I'Unione di Comuni Valdarno e Valdisieve e la Regione Toscana. Accordi specifici sono in essere con gli istituti culturali (associazioni e fondazioni) che operano nella Valdisieve e con gli stakeholder locali. Per le operazioni di digitalizzazione dei beni culturali, il gruppo di lavoro si avvale anche della collaborazione dell'Università Politecnica delle Marche e, in particolare, del DiStoRi Heritage.

[7] Sui rilievi 3D [Sanna 2015, pp. 219-225].

[8] Durante questa operazione è stato necessario intervenire sui seguenti parametri: DetectEdges (riconosce in automatico gli spigoli del modello per poterli meglio preservare), Target Polygons Count (consente di definisce il numero dei poligoni desiderati, nel caso in studio valori compresi fra 30 e 50 hanno prodotto risultati soddisfacenti in termini di riduzione di poligoni e di qualità della geometria finale), Adapt (l'opzione è stata disattivata), Adaptive Size (questa funzione impostata su valori bassi consente la generazione di poligoni quadrati piuttosto che triangolari).

[9] I parametri di default sono risultati efficaci.

[ I 0] Sono state generate mappe 4k con i parametri di default, fatta eccezione per il numero dei secondary rays relativi al calcolo dell'ambient occlusion e della curvature che è stato incrementato fino al valore massimo.

[I I ] II dato orografico è presente in tutte le formelle ad eccezione di quella con l'Incontro fra Salomone e la Regina di Saba.

[12] Cfr. Mibact, Piano triennale per la digitalizzazione e l'innovazione dei musei. <http://musei.beniculturali.it/wp-content/ uploads/20 I 9/08/Piano-Triennale-per-la-Digitalizzazione-e-l'Innovazione-dei-Musei.pdf> (consultato il 5 maggio 202 I). 


\section{Riferimenti bibliografici}

Apollonio F.l. et al. (2017). Photogrammetry driven tools to support the restoration of open-air bronze surfaces of sculptures: An integrated solution starting from the experience of the Neptune Fountain in Bologna. In Remote Sensing, n. 42, pp. 47-54.

Apollonio F.l. et. al. (202I). A Photogrammetry-Based Workflow for the Accurate 3D Construccion and Visualization of Museum Assets. In Remorte Sensing, n. 13, pp. I 8-24.

Berthelot M. et. al. (20I5). The Avignon Bridge: A 3D reconstruction project integrating archaeological, historical and geomorphological issues. In Remote Sensing, n. 40, pp. 223-227.

Borsi F. ( 1978). Le architetture del Ghiberti. In AA.VV. Lorenzo Ghiberti. Materia e Ragionamenti, pp. 462-464. Firenze: Centro Di.

Caudullo T. (2020). Scansione laser 3D: tecnologia al servizio della tutela dei beni culturali. In Archeomatica, n. 3/4.

Ciardi Duprè Dal Poggetto M.G. (1978). Porta del Paradiso. Introduzione. In AA.V. Lorenzo Ghiberti. Materia e Ragionamenti. pp. 330-332. Firenze: Centro Di.

Ciatti M. (20 I5). Introduzione. In Giusti A. (a cura di.). II Paradiso ritrovato. II restauro della Porta del Ghiberti, pp. I3- I5. Firenze: Mandragore.

Degl'Innocenti G. (1978). Problematica per l'applicazione della metodologia di restituzione prospettica a tre formelle della porta del Paradiso di Lorenzo Ghiberti: proposte e verifiche. In AA.V. Ghiberti e l'architettura, pp. I27-I28. Firenze: Università degli Studi di Firenze.

Gabellone F. (2020). Archeologia Virtuale. Teoria, Tecniche e Casi di Studio. Lecce: Edizioni Grifo.

Gaiani M. (20I5). I Portici di Bologna Architettura. Modelli 3D e Ricerche Tecnologiche. Bologna: Bononia University Press.

Giusti A. (20I5). Un comune impegno di conoscenza, esperienza, passione. In Giusti A. (a cura di). II Paradiso ritrovato. II restauro della Porta del Ghiberti, pp. 166-175. Firenze: Mandragore.

Giusti A., Radke G.M. (20I2). La porta del Paradiso. Dalla bottega di Lorenzo Ghiberti al cantiere di restauro. Firenze: Giunti.

Guidi G., Angheleddu D. (2016). Displacement Mapping as a Metric Tool for Optimizing Mesh Models Originated by 3D Digitization. In Journal on Computing and Cultural Heritage. n. 9, pp. I-23.

Gurrieri F. (20|4). L'architettura delle formelle Ghibertiane. In Verdon T. (a cura di). La porta d'oro del Ghiberti, pp. 75-79. Firenze: Madragora.

Krautheimer R., Krautheimer-Hess T. (1970). Lorenzo Ghiberti. Princeton: Princeton University press.

Masotti L., Calzolai M. (20 I5). Calcoli e procedure per lo smontaggio e rimontaggio dei rilievi. In Giusti A. (a cura di). II Paradiso ritrovato. II restauro della Porta del Ghiberti, p. 2 I 3 Firenze: Mandragore.

Merlo A., et. al. (20I2). The mayan mascaron from Chilonché (Péten, Giatemala): new techologies for cultural heritage dissemination. In AA.V. Proceeding of CHNT 17, Museen der Stadt Wien, Vienna: Stadtarchaologie.

Merlo A., Lavoratti G. (2020). Ghibertiana. Documentazione e valorizzazione dell'opera di Lorenzo Ghiberti. In Belardi P. (a cura di). Riflessioni: l'arte del disegno/il disegno dell'arte / Reflections: the art of drawing/the drawing of art. Atti del $41^{\circ}$ Convegno internazionale dei Docenti delle discipline della Rappresentazione / Proceedings of the 4 I $^{\text {th }}$ International Conference of Teachers of the disciplines of the Representation, pp. 817-824. Roma: Gangemi Editore.

Paris L. (20|4). Dal problema inverso della prospettiva al raddrizzamento fotografico. Roma: Aracne Editrice.

Russo M., Guidi G. (20I I). Reality-based and reconstructive models: digital media for cultural heritage valorization. In SCIRES vol. I, issue 2, pp. 7 I-86.

Sanna L., Ursini E. (20 I5). II contributo del rilievo digitale al restauro della Porta del Paradiso. In Giusti A. (a cura di.). II Paradiso ritrovato. II restauro della Porta del Ghiberti, pp. 2 19-225. Firenze: Mandragore.

Siano S. (20 I5). La lettura materica della Porta del Paradiso. In Giusti A. (a cura di.). II Paradiso ritrovato. II restauro della Porta del Ghiberti, pp. 67-80. Firenze: Mandragore.

Autori

Alessandro Merlo, Università degli Studi di Firenze, alessandro.merlo@unifi.it

Matteo Bartoli, Università degli Studi di Firenze, matteo.bartoli@unifi.it

Per citare questo capitolo: Merlo Alessandro, Bartoli Matteo (2021). Modelli interpretativi a servizio dell'arte: la porta del paradiso di Lorenzo Ghiberti/Interpretative Models Employed by Art: the Gates of Paradise by Lorenzo Ghiberti. In Arena A.,Arena M. Mediati D. Raffa P. (a cura di). Connettere. Un disegno per annodare e tessere Linguagoi Distanze Tecnologie. Atti del $42^{\circ}$ Convegno Internazionale dei Docenti delle Discipline della RappresentazionelConnecting Drawing for weaving relationship. Languaes Distances Technologies. Proceedings of the 42 th International Conference of Representation Disciplines Teachers. Milano: FrancoAngeli, pp. 2493-2512. 


\title{
Interpretative Models Employed by Art: the Gates of Paradise by Lorenzo Ghiberti
}

\author{
Alessandro Merlo \\ Matteo Bartoli
}

Abstract

The Gates of Paradise in the Florence Baptistery [I], created by Lorenzo Ghiberti between 1427 and I 452, is recognised as one of the works that marked the transition from the Medieval Art to Renaissance Art by art critics [Krautheimer 1970, pp. 298-305]. The bas-reliefs of the ten bronze panels showcase, from both an iconographic and a technical point of view, a marked difference from the previous production, even by the same master. The element that endures through this change is the narrative function of art; in the Christian art, the figurative language continues to play an important catechetical role [Ciardi Duprè Dal Poggetto 1978, pp. 330-332]. In order to fully understand the meaning of the transfigured text, it is necessary, both today and in the past, to possess the reading codes. Over the centuries these codes have gradually been lost, thus making the scenes depicted in the door partially 'mute'.

The contribution intends to illustrate an experience carried out by a group of researchers from DIDA (University of Florence) CHMLab, in collaboration with the Opera di Santa Maria del Fiore Museum in the field of digital humanities, aimed at analysing and restoring, through 3D modelling and animation, the events that took place within the 'landscape of the panels', creating a renewed and more immediate reading. (A.M.).

Keywords

cultural heritage, 3D modelling, digital humanities, Gates of Paradise, Ghibertiana.

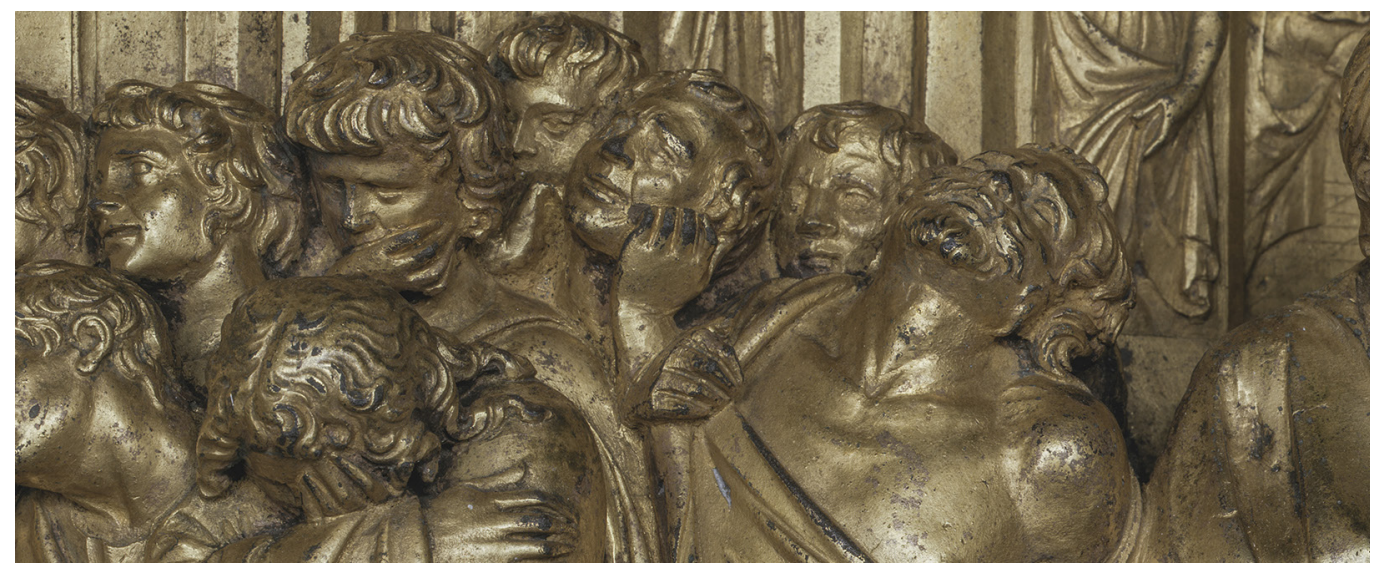


The panels of the Gates of Paradise

Two of the three doors of the Florence Baptistery were commissioned to Ghiberti: the second (I403-1424) with the Stories from the Life of Christ, and the third (1425-1452) depicting the Stories of the Old Testament (fig. I).

The results of the famous competition of 1403, in which the young Ghiberti prevailed over Filippo Brunelleschi and was entrusted with the realisation of the second door, highlighted not only his extraordinary skills as a sculptor and chiseller, but above all his use of a new casting technique, that allowed for the creation of thin and more easily modelled surfaces [Siano 2015, pp. 67-80]. Breaking with a millenary tradition that had seen bronze doors decorated with a great number of individual panels (28 in the case of the first door by Andrea Pisano and the second door), the author describes in the third door the stories included in the first books of the Bible with only ten panels [2], and at the same time abandoning the quatrefoil by replacing it with the square format [Giusti, Radke 2012, p. 68].

The scenes in each panel (sometimes up to nine events reunited in the same work) are depicted on a plurality of planes. Unlike what one might expect from a rigorous application of perspective, very well known by the master, according to which the more distant figures should be smaller and in bas-relief, Ghiberti emphasises his scenes by projecting, almost arriving to a sculpture in the round, not only the elements in the foreground, but also those in the background, masterfully distorting and foreshortening the figures (fig. 2). (A.M.).

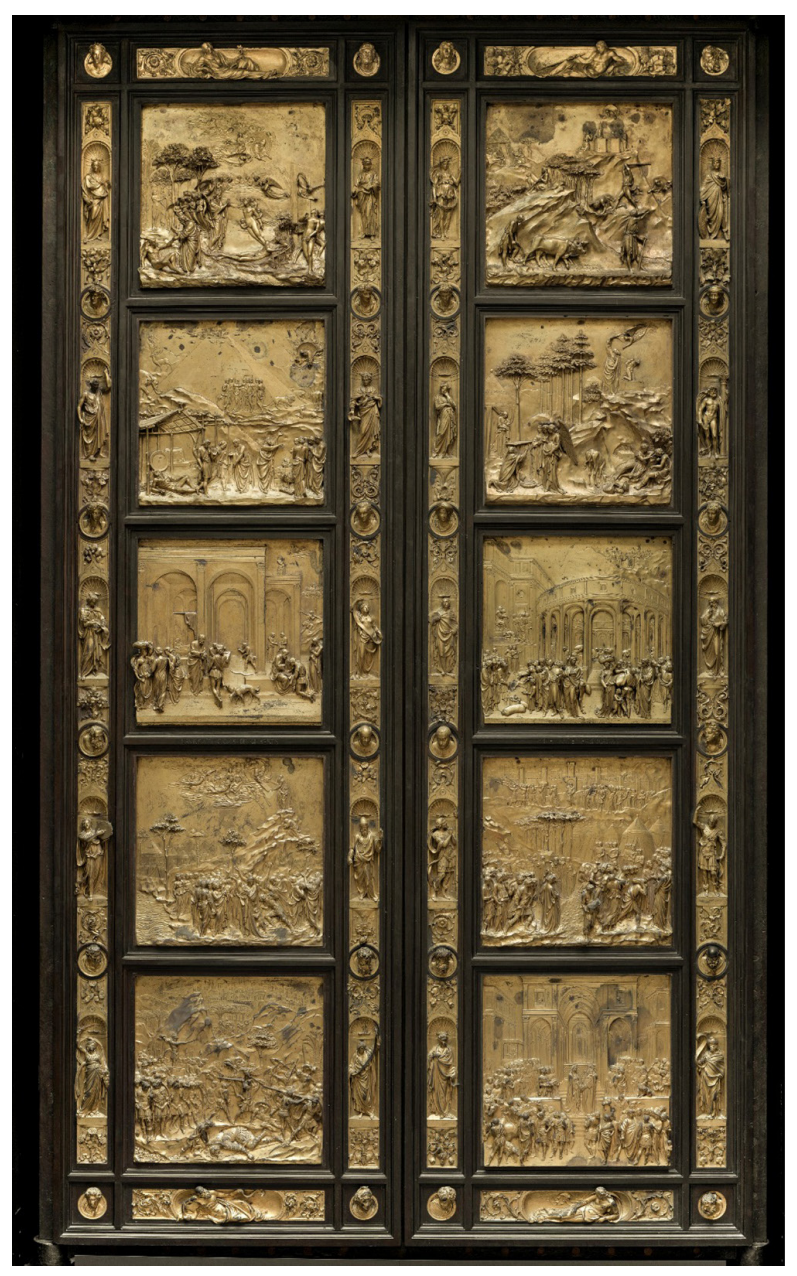

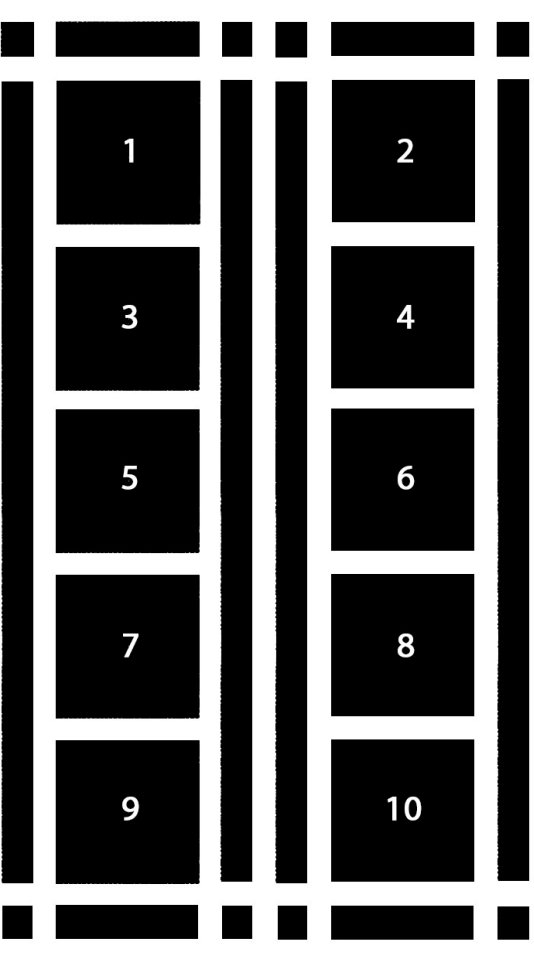

Storie di:

1. Adamo ed Eva, 2. Caino e Abele, 3. Noè, 4. Abramo, 5. Giacobbe ed Esaù, 6. Giuseppe, 7. Mosè,

8. Giosuè, 9. Davide, 10. Salomone. 


\section{The 'Ghibertiana’ Project}

The experience covered by this contribution is part of a complex, interdisciplinary and multi-scalar project, called 'Ghibertiana' [3], whose aim is to enhance the link between the cultural heritage of the lower Valdsieve and the works of Lorenzo Ghiberti (Pelago 1378 Firenze 1455), who, in this land, was born and invested part of his fortune [4].

The project includes the realisation of the Documentation Centre on Lorenzo Ghiberti in which all the information on the artist and his works will be collected in dematerialised form, allowing scholars to find a dedicated place for their researches on the master -and the Interpretation Centre of the lower Valdisieve- where it will be possible to acquire the keys to decode, with the correct historical perspective, the places of greatest interest in this part of the territory (Ghiberti's homeland) [5]. Using the obvious, but highly effective, metaphor of the 'door', this Centre will allow visitors, once they have crossed its threshold, to grasp those elements found in the early $15^{\text {th }}$ century in the landscape of the lower Valdisieve, which Ghiberti often depicted in his works and that still remain today as an indelible sign of man's work [6]. In particular, Room 5, the one dedicated to the Gates of Paradise, will host the 3D prints of the ten panels (each one measuring $80 \times 80 \mathrm{~cm}$ [Masotti 20 I5, p. 213]) realised by the master for the Baptistery of St. John in Florence, and recreated in a plastic material, on a scale of I:I without the chromatic data. The copies, placed at such a height, as to allow visitors to have a unique tactile experience, will also allow the visually impaired to appreciate the numerous planes in which Ghiberti depicted architecture, landscapes, animals and characters described in the prophets' stories.

In addition, each panel will act as a target, enabling a 3D animation to be activated on a device (a tablet to be used free of charge by visitors for the duration of their visit, or a personal mobile device) that will project the user into the space represented by the master. The image framed by the camera will be progressively replaced by frames with renderings of the 3D model of the panel and its apparent colour.The video sequences, specially-made in order to frame only those parts of the meshes that it has been possible to generate from the original representations, will make it possible to describe, in the correct temporal sequence, the multiple events that Ghiberti portrayed within the same panel. At the same time the voice of a narrator will provide an explanation of those events with reference to the biblical text. (A.M.).
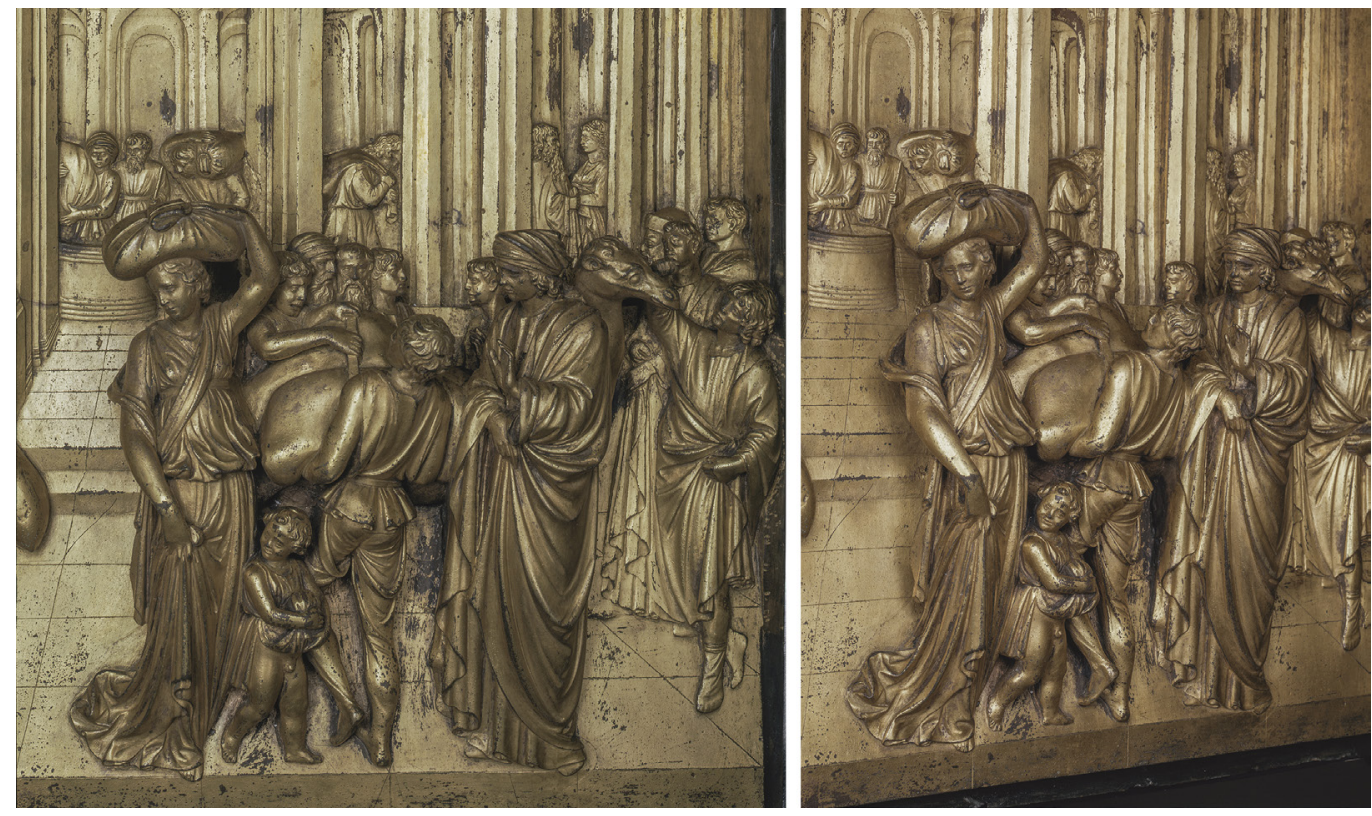
Fig. 3. Lorenzo Ghiberti Gates of Paradise, Stories of Joseph (sixth tile).

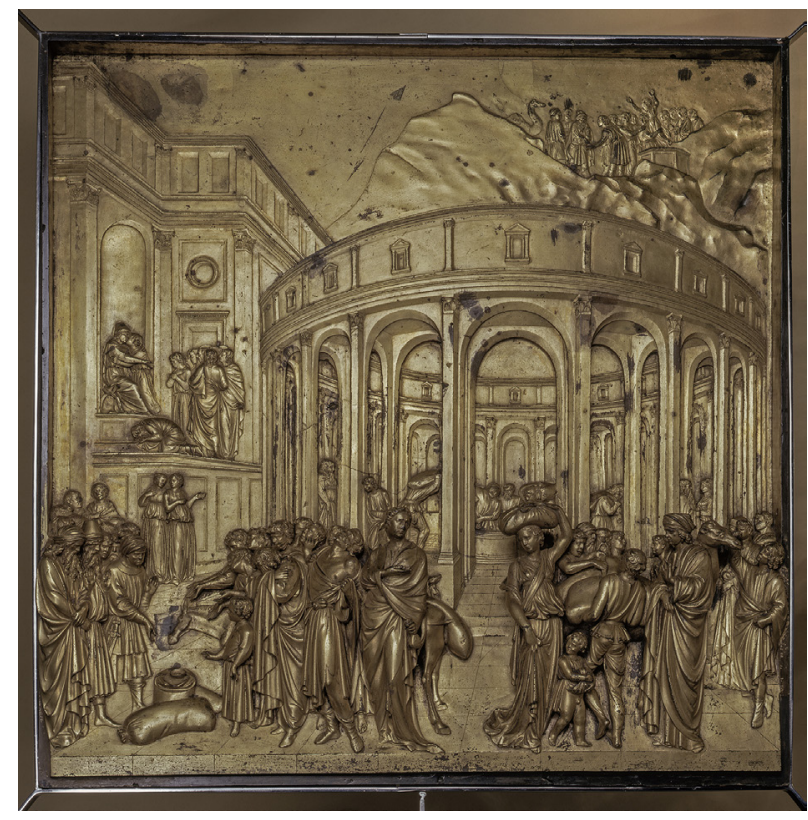

The panel with The Stories of Joseph

In order to illustrate in detail the operations carried out on the individual panels, we examine here the work (sixth panel, fig. 3) with The Stories of Joseph and his Brothers, to which the images in the text also refer to.

The master opens the visual narrative in the top right-hand corner with an illustration of the text from Genesis 37:28: "Then Midianite traders passed by. And they (Joseph's brothers) drew Joseph up and lifted him out of the pit, and sold him to the Ishmaelites for twenty shekels of silver. They took Joseph to Egypt". The second episode explicitly illustrated by Ghiberti, in the background below the large arched structure, is taken from Genesis 41:4849: "Joseph collected all the food produced in those seven years of abundance in Egypt and stored it in the cities. In each city he put the food grown in the fields surrounding it. Joseph stored up huge quantities of grain, like the sand of the sea; it was so much that he stopped keeping records because it was beyond measure". The third biblical passage depicted, in the foreground on the bottom right, is from Genesis 41:56-57: "When the famine had spread over the whole country, Joseph opened all the storehouses and sold the grain to the Egyptians, for the famine was severe throughout Egypt. And all the world came to Egypt to buy grain from Joseph, because the famine was severe everywhere". The fourth passage depicted, in the left foreground, is from Genesis 44:11-13, in which, Joseph's brothers face the accusation of Joseph's servant that in one of the sacks of grain that they were taking back to Canaan there was a silver cup stolen from Joseph's house, "Then each man speedily let down his sack to the ground, and each opened his sack. So he (the servant) searched them. He began with the oldest and left off with the youngest; and the cup was found in Benjamin's sack. Then they (the brothers) tore their clothes, and each man loaded his donkey and returned to the city". The fifth and last biblical passage depicted, above the scene of Benjamin's sack, is from Genesis 45:3 and 45: I 4, in which Joseph makes himself known:"And Joseph said to his brothers, 'I am Joseph! Is my father still alive?' But his brothers could not answer him, for they were dismayed at his presence. Then he fell upon his brother Benjamin's neck and wept, and Benjamin wept upon his neck".

In this panel, like in the fifth and the tenth, the individual episodes take place primarily in an urban setting. Excluding the first episode, which takes place on the crest of a hill, the second takes place inside a circular building that serves as a granary (in the centre is the grain pit), the third and fourth take place in the square in front of it and the last takes place on a podium, which is an integral part of a classical building. Apart from the possible analogies 
Fig. 4. Perspective reconstruction of the tile with the Stories of Joseph.

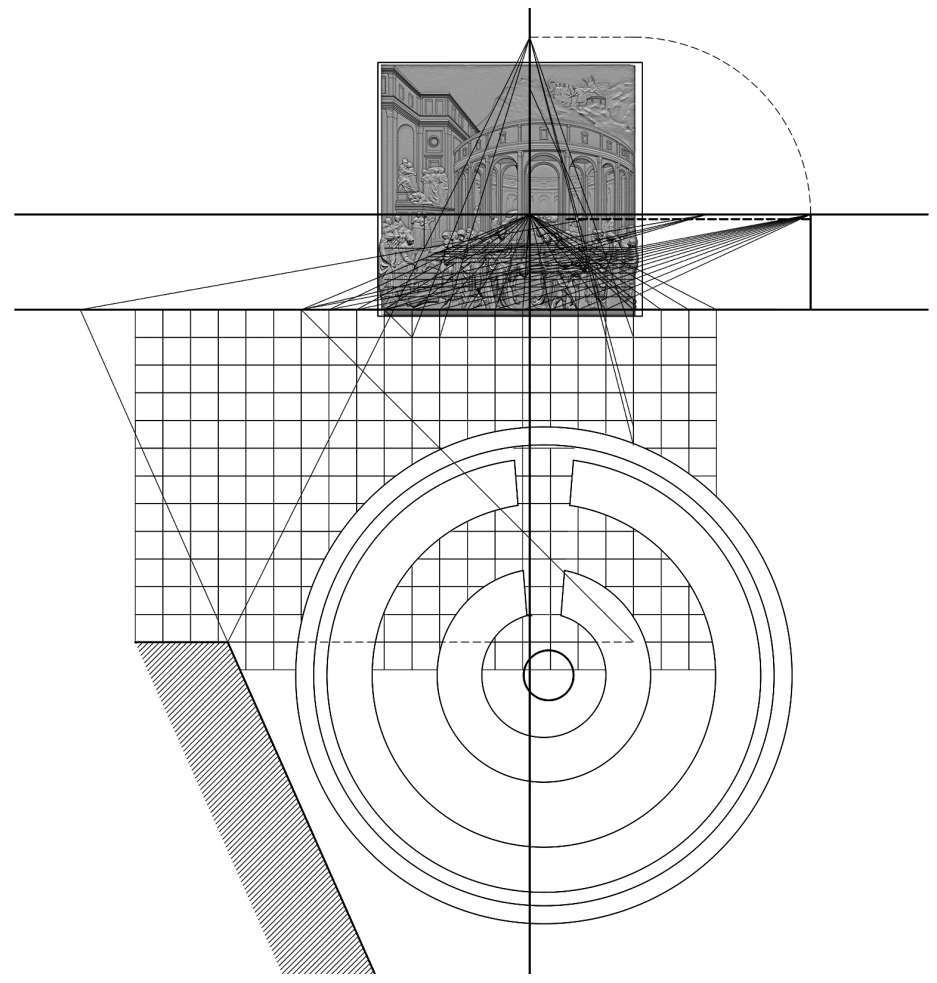

with buildings that Ghiberti may have seen during his travels or taken from other works [Gurrieri 20I4, pp. 75-79], they are fictional architectures that are functional to the story, in which the master composes elements of Greco-Roman antiquity in a new form [Borsi 1978, p. 464].

Compared to the panels in which the episodes take place in bucolic landscapes, the underlying geometries of the buildings and floors make it easier to infer the compositional layout.

In The Stories of Joseph, for example, once the frontal image of the panel had been obtained by rendering the high-poly model and assuming that the floors were subdivided by square meshes placed parallel to the work, it was possible to trace the fundamental elements of perspective and, subsequently, the positions and reciprocal relationships between the various parts of the building, which were modelled and repositioned within the 3D space (fig. 4).

This exercise, functional to the purpose of the project, made it possible to confirm the correct use of the conical projection by the master (at least for the representation of the elements on the ground), also taking into account the presence of numerous projecting parts that were modelled to support the perspective itself.

The reasons of the art, that oversee everything, also meant that Ghiberti intentionally adjusted the forms to the narrative [Degl'Innocenti 1978, pp. 127-128]. The grain pit, for example, is not placed in the centre of the circular building, but shifted to the left in order not to be obscured by the figures in the foreground. The vanishing point of the floor leading towards the pit has also been moved from its place to emphasise the view of the pit itself; all the elements above the vanishing line have their 'focus' above the latter, probably so as not to excessively distort the figures in the upper $2 / 3$ of the panel. (A.M.).

\section{Modelling and texturing operations}

The research group had access to the high-poly models of the panels created following their morphometric documentation [7] during the restoration work [Giusti 20 I5, pp. 166- I75]. The original model with Joseph's stories, for example, consists of 26,3 I2,297 polygons with an average length of the even side of $0.278 \mathrm{~mm}$ (file size $1.284 \mathrm{~Gb}$, fig. 5). 


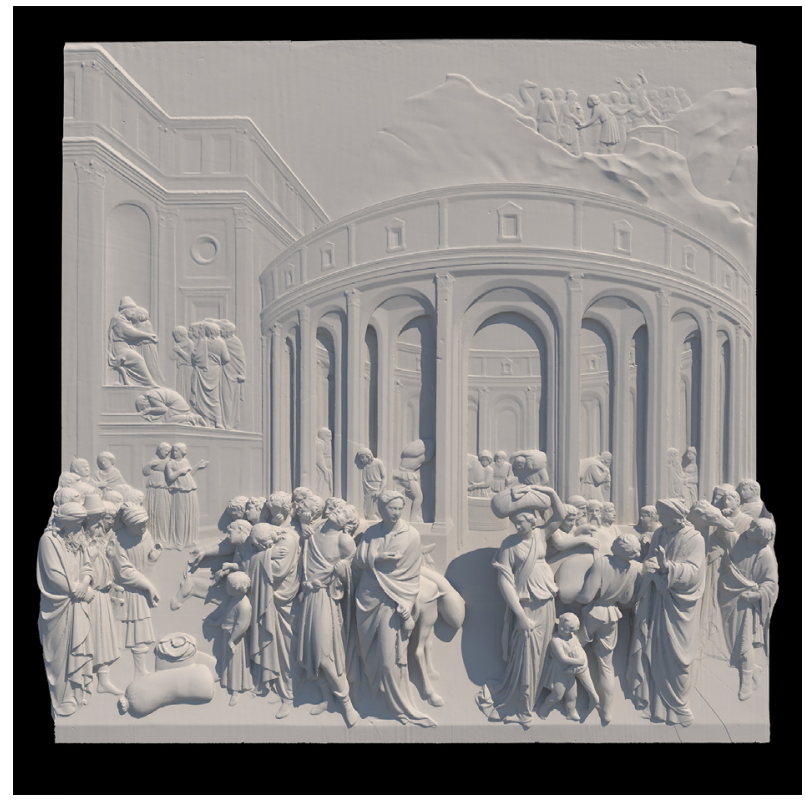

In order to fulfil the goals of the project it was necessary, for each panel and starting from their digital copy, to create 3D models of both the scenes in which the individual episodes take place and the characters and objects found in them.

In order to identify the elements useful to the recomposition of the three-dimensional scene, it was necessary to distribute the various components according to two distinct parameters: one linked to the role played in the narration of the biblical episodes, the other to the starting spatial data (i.e. their projection).

Once the groups had been defined, each element was isolated from the others and from the background, and underwent an initial decimation process using the Geomagic software (reducing the number of polygons by 30\%), which also made it possible to generate isotropic surfaces (fig. 6). Subsequently, the individual components were imported into the Zbrush program and subjected to a semi-automatic retopology process using the Zremesher's function [8], which made it possible to further reduce the number of polygons and to generate quad-dominant meshes, which generally provide better results when parameterizing the models (fig. 7).

In order to compensate for the loss of geometric data and, consequently, of the details carved by the artist, it was decided to rely on u,v maps. In order to apply these maps, firstly it was necessary to parameterize the high-poly models using the autounwrap function of the Substance Painter program, which effectively combines speed of execution and quality of results (fig. 8) [9]. The maps used, in addition to the normal maps, such as the Ambient occlusion map and the Curvature map, were obtained by using the Bake Mesh Map command of the same software [10].

In order not to introduce arbitrary components, it was decided in advance to leave the figures unchanged and, therefore, not to reconstruct the missing parts.

A different approach was taken with regard to the components that define the scenes, whether they were architecture (fifth, sixth and tenth panel) or hilly/mountainous landscapes. In this case, in fact, the presence of gaps would have resulted in condemning any attempt to document the elements depicted by the master within a continuous three-dimensional space to being useless.

The architectures were completely reconstructed by direct modelling in a 3ds Max environment, starting from the results of the perspective reconstruction (fig. 9).

Hills and mountains [I I], that Ghiberti represents in the form of more or less sloping rocky cliffs, were created through a manual retopology operation, still within 3ds Max, carefully following the profiles and angles, subsequently emphasized through the displacement and turbosmooth modifiers. 
Fig. 6. Lorenzo Ghiberti, Gates of Paradise Stories of Joseph (medium-poly detail figures)

Fig. 7. Lorenzo Ghiberti, Gates of Paradise, Stories of Joseph (detail of the retopology of a group of figures).
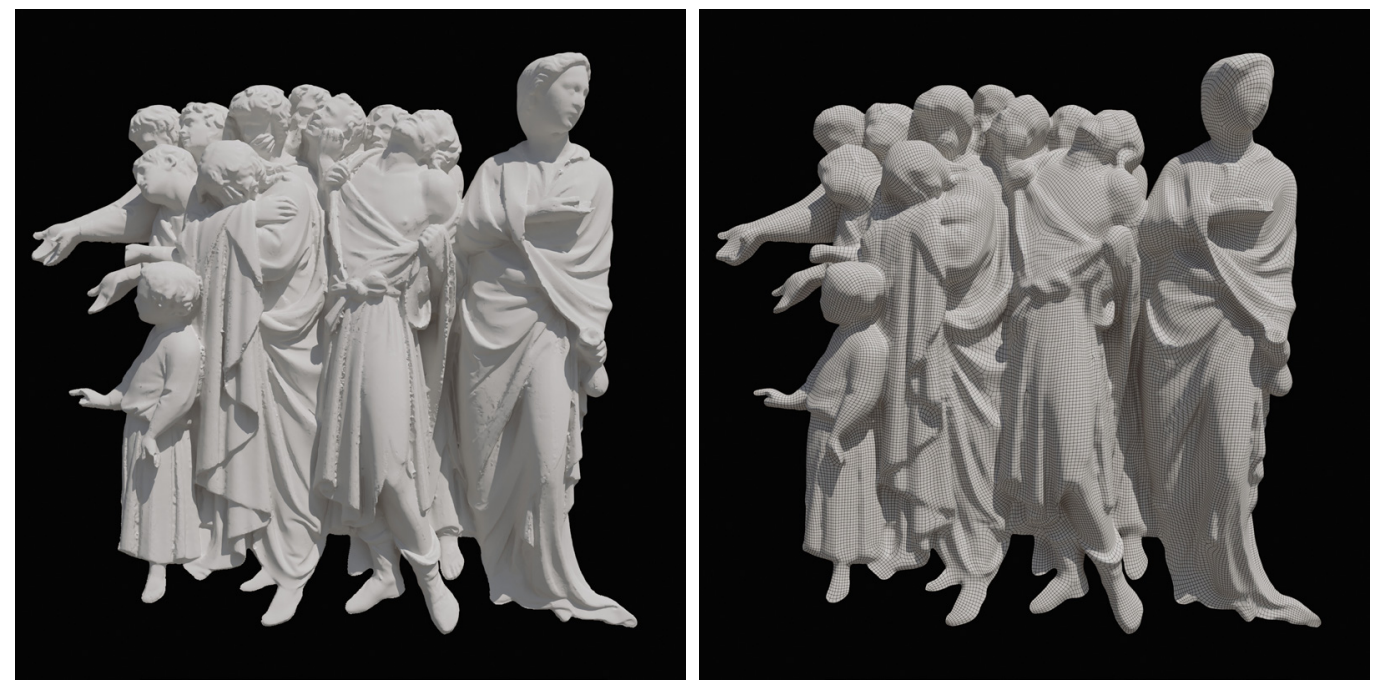

As a result of the perspective, to avoid the creation of large areas that have not been described by the artist, the mountains placed in the background have been modelled by using the same dimensions that they have in the panels. Thanks to this expedient, in fact, it was possible to significantly reduce the distances between elements in the foreground and those in the background.

In each panel, characters, objects, plants and animals project from the plane to which they are anchored with different degrees; some are barely engraved on the bronze plate, while others mimic the sculpture in the round. Also in this case, where it was considered appropriate to bring out the details, they were employed once more the displacement maps.

As far as texturing is concerned, it was decided to resort to the procedural maps. The Substance Painter program allowed firstly to employ a material, a metal in this case, which simulates the mercury gilding imprinted on the panels, to which procedural maps were subsequently applied (Grunge map, Scratches map, etc.), and this made it possible to customize the material by acting on the many parameters available. Once the desired effect was achieved, the program made it possible to export specially-made 4K maps for Corona Renderer (diffuse maps, glossiness maps, reflection maps, height maps, IOR maps) that were used to texturize the models. Given the large number of objects presented in the same scene, the selection of this method allowed a simpler and more immediate control over the results obtained (figs. IO, II). (M.B.).

\section{D animation}

The decision to leave the figures unaltered and, therefore, not to reconstruct the missing parts, drastically limited the possibility of moving the camera as much as desired within the three-dimensional space, constraining it to the pre-set positions from which only the elements actually modelled by the artist would be filmed and at the same time hiding the previously described gaps from view.

The animated sequences were created on the basis of the storyboard to explore the 'landscape of art' depicted by Ghiberti.

The animation of parts of textures obtained from high-definition photographs of the panels represented an effective expedient to provide greater dynamism to the scenes while remaining as faithful as possible to the work of the artist, in addition to the small movements impressed on the mesh through rigging techniques. This expedient was particularly useful to simulate, for example, the movement of the water; in this case a noise modifier was added to the animation of the texture, which was also animated, in order to simulate the flow of a stream. (M.B.). 
Fig. 8. Lorenzo Ghiberti, Gates of Paradise, Stories of Joseph (detail of the parameterization of group of figures).

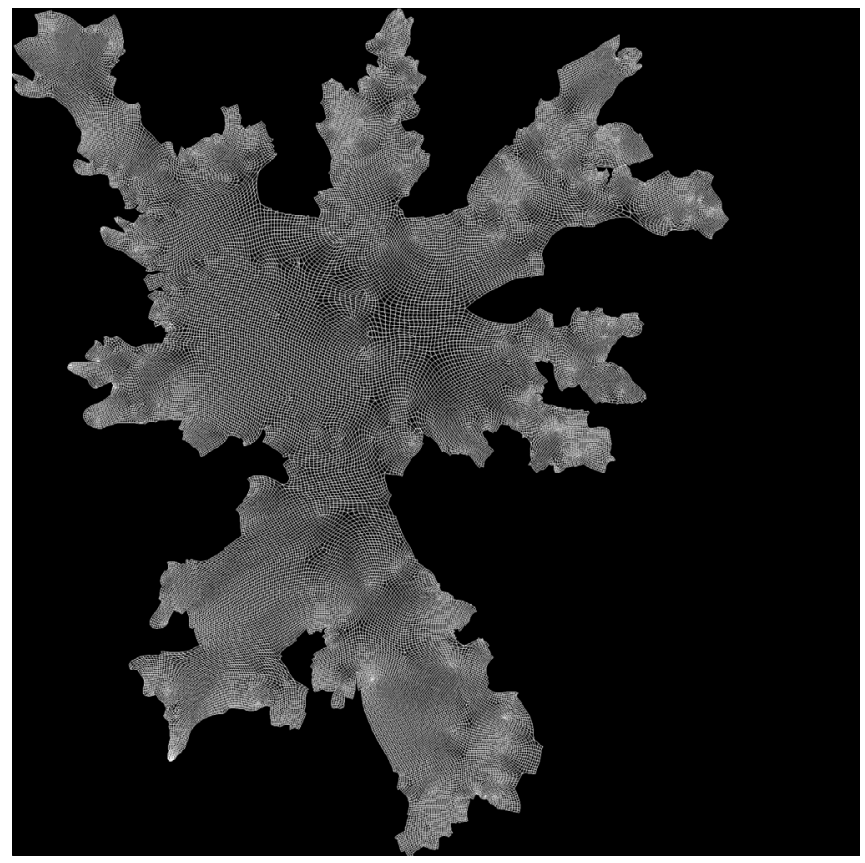

\section{Conclusions}

Today's digital technologies make it possible to enjoy the cultural heritage in new ways, closer to the expectations, not only those of a non-specialist public, but increasingly also those of the professionals. Having overcome the initial preconception, which for many years and in part still today meant that the scientific value of these products wasn't recognised, there are many initiatives in all areas of research that are pushing towards the use of virtual reality and its many declinations ( $A R, I R$ and $M R$ ) and uses (from 3D animation to multimedia applications). The indications expressed in the Ministerial Directives for the museums 4.0 [12], for example, confirm the path taken. In the field of humanities, the digital humanities are now a well-established reality and a constantly evolving field of research; as in the case analysed here, the digital technologies, on the one hand, open up new horizons of interpretation, and on the other, make it possible convey the results obtained in a successful manner. (A.M.).
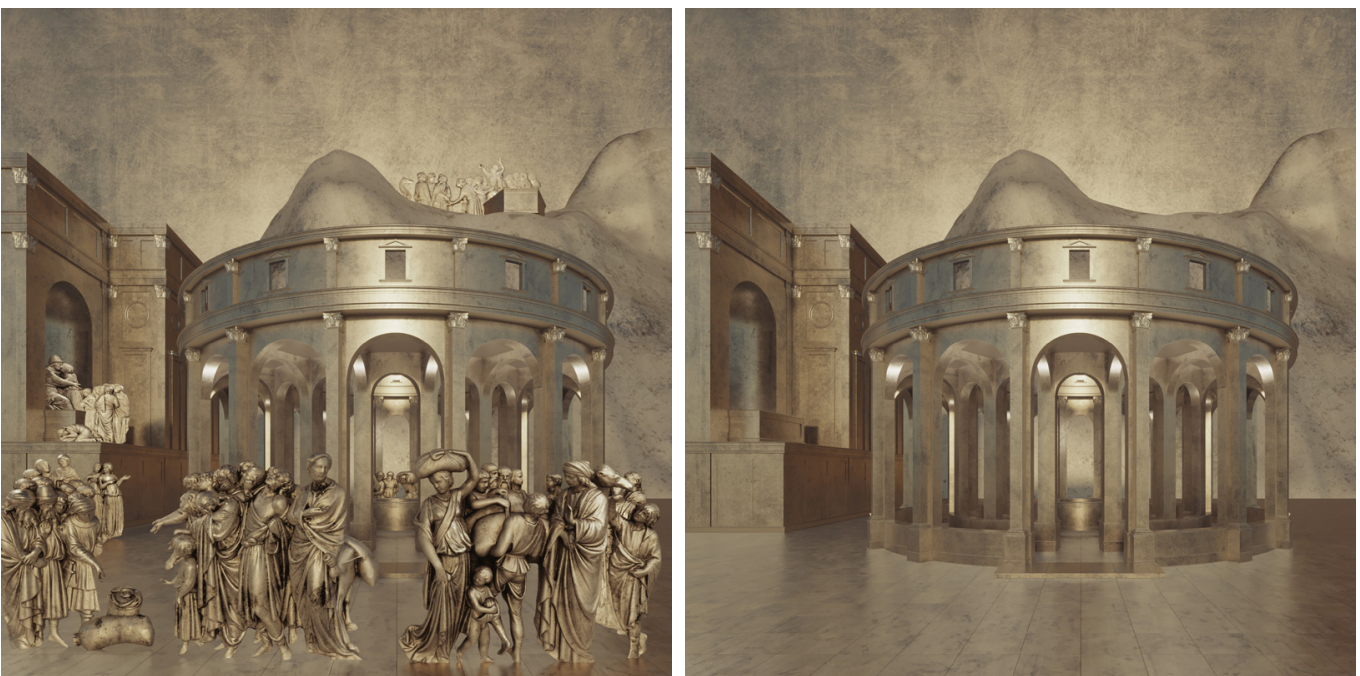

Fig. 9. Render of the scene with only the architectures of the tile with the Stories of Joseph. 


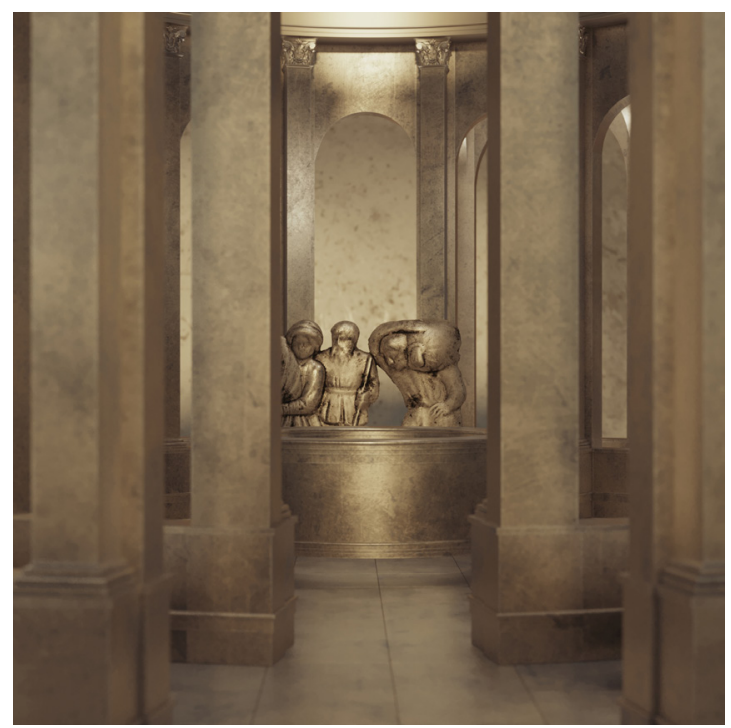

\section{Acknowledgements}

Thanks to Prof. Filippo Fantini for its contribution to the definition of the work pipeline for the realization of the 3D models, Monsignor Timothy Verdon (Director) and Dott. Giovanni Serafini of the Museo dell'Opera di Santa Maria del Fiore for the analysis of the sacred texts and the drafting of the storyboard and, finally, Prof. Giuseppina Carla Romby for the historicalfigurative reading of the architectures represented by Ghiberti.

\section{Notes}

[I] "The Baptistery of St. John in Florence is one of the monuments that symbolises the city and its historical and religious identity... sponsored by the powerful and wealthy Arte di Calimala, a guild of merchants who acted on an international level. All these reasons demonstrate why the Florence Baptistery had, between the Middle Ages and the Renaissance, some of the most important artistic commissions in the city" [Ciatti 20 I5, p. I3].

[2] The stories depicted in the 10 panels pertain to: Adam and Eve, Cain and Abel, Noah, Abraham, Jacob and Esau, Joseph, Moses, Joshua, David and, finally, Solomon.

[3] For further information about the Project, cf. www.ghibertiana.it (accessed 2021, May 5).

[4] 'Ghibertiana' is a university project created by the collaboration of the Department of Architecture (DIDA) and the Department of History, Archaeology, Geography, Art, Performing Arts (SAGAS) of the University of Florence.Alessandro Merlo and Giuseppina Carla Romby are the coordinators of the Project; The Scientific Committee is composed by them, Paolo Clini and the Supervisors of each exhibition hall (Dora Liscia Bemporad, Paolo Nanni, Francesco Salvestini, Guido Vannini with Chiara Molducci).

[5] The Interpretation Centre of the lower Valdisieve and the Documentation Centre on Lorenzo Ghiberti will be housed in the town hall built in the 14 th-century in the castle of Pelago. This historic building, owned by the municipality bearing the same name, was restored in 2017 for museum-related purposes and, since 201 8, it has been assigned to the Project.

[6] In the last three years, there has been the formalisation of agreements with the Opera di Santa Maria del Fiore, the Opificio delle Pietre Dure, the Accademia dei Georgofili, the Museo dell'Opera del Duomo, and recently with the Uffizi Galleries. As far as the agreements with local authorities are concerned, the Project involves the Union of municipalities of Valdarno and Valdisieve and the Region of Tuscany. Moreover, there are specific agreements in place with cultural institutions (associations and foundations) operating in Valdisieve and with local stakeholders. The research group is also collaborating with the Marche Polytechnic University and, in particular, with DiStoRi Heritage for the digitisation of cultural heritage.

[7] About 3D surveys [Sanna, Ursini 2015, pp. 219-225].

[8] The following parameters had to be adjusted during this operation: DetectEdges (automatically recognises the model's edges in order to better preserve them), Target Polygons Count (allows to define the number of polygons desired; in this case, values between 30 and 50 produced satisfactory results in terms of polygon reduction and quality of the final geometry), Adapt (the option has been deactivated), Adaptive Size (this function once set to low values allows the generation of square polygons rather than triangular ones).

[9]The default parameters were found to be effective.

[10]The 4k maps generated saw the use of default parameters, except for the number of secondary rays for the calculation of the ambient occlusion and curvature, which was increased to the maximum value.

$[\mathrm{II}]$ The orographic data is present in all the panels except for the one depicting the Meeting between King Solomon and the Queen of Sheba.

[12] Cfr. Mibact, Piano triennale per la digitalizzazione e l'innovazione dei musei. <http://musei.beniculturali.it/wp-content/ uploads/2019/08/Piano-Triennale-per-la-Digitalizzazione-e-l'Innovazione-dei-Musei.pdf> (accessed 202 I, May 5). 


\section{References}

Apollonio F.l. et al. (2017). Photogrammetry driven tools to support the restoration of open-air bronze surfaces of sculptures: An integrated solution starting from the experience of the Neptune Fountain in Bologna. In Remote Sensing, n. 42, pp. 47-54.

Apollonio F.l. et. al. (202I). A Photogrammetry-Based Workflow for the Accurate 3D Construccion and Visualization of Museum Assets. In Remorte Sensing, n. 13, pp. I 8-24.

Berthelot M. et. al. (20I5). The Avignon Bridge: A 3D reconstruction project integrating archaeological, historical and geomorphological issues. In Remote Sensing, n. 40, pp. 223-227.

Borsi F. ( 1978). Le architetture del Ghiberti. In AA.VV. Lorenzo Ghiberti. Materia e Ragionamenti, pp. 462-464. Firenze: Centro Di. Caudullo T. (2020). Scansione laser 3D: tecnologia al servizio della tutela dei beni culturali. In Archeomatica, n. 3/4.

Ciardi Duprè Dal Poggetto M.G. (1978). Porta del Paradiso. Introduzione. In AA.V. Lorenzo Ghiberti. Materia e Ragionamenti. pp. 330-332. Firenze: Centro Di.

Ciatti M. (20 I5). Introduzione. In Giusti A. (a cura di.). II Paradiso ritrovato. II restauro della Porta del Ghiberti, pp. I3- I5. Firenze: Mandragore.

Degl'Innocenti G. (1978). Problematica per l'applicazione della metodologia di restituzione prospettica a tre formelle della porta del Paradiso di Lorenzo Ghiberti: proposte e verifiche. In AA.V. Ghiberti e l'architettura, pp. I27- I 28. Firenze: Università degli Studi di Firenze.

Gabellone F. (2020). Archeologia Virtuale. Teoria, Tecniche e Casi di Studio. Lecce: Edizioni Grifo.

Gaiani M. (20I5). I Portici di Bologna Architettura. Modelli 3D e Ricerche Tecnologiche. Bologna: Bononia University Press.

Giusti A. (20I5). Un comune impegno di conoscenza, esperienza, passione. In Giusti A. (a cura di). II Paradiso ritrovato. II restauro della Porta del Ghiberti, pp. I66-175. Firenze: Mandragore.

Giusti A., Radke G.M. (20I2). La porta del Paradiso. Dalla bottega di Lorenzo Ghiberti al cantiere di restauro. Firenze: Giunti.

Guidi G., Angheleddu D. (2016). Displacement Mapping as a Metric Tool for Optimizing Mesh Models Originated by 3D Digitization. In Journal on Computing and Cultural Heritage. n. 9, pp. I-23.

Gurrieri F. (20|4). L'architettura delle formelle Ghibertiane. In Verdon T. (a cura di). La porta d'oro del Ghiberti, pp. 75-79. Firenze: Madragora.

Krautheimer R., Krautheimer-Hess T. (1970). Lorenzo Ghiberti. Princeton: Princeton University press.

Masotti L., Calzolai M. (20 I5). Calcoli e procedure per lo smontaggio e rimontaggio dei rilievi. In Giusti A. (a cura di). II Paradiso ritrovato. II restauro della Porta del Ghiberti, p. 2 I 3 Firenze: Mandragore.

Merlo A., et. al. (20I2). The mayan mascaron from Chilonché (Péten, Giatemala): new techologies for cultural heritage dissemination. In AA.V. Proceeding of CHNT 17, Museen der Stadt Wien, Vienna: Stadtarchaologie.

Merlo A., Lavoratti G. (2020). Ghibertiana. Documentazione e valorizzazione dell'opera di Lorenzo Ghiberti. In Belardi P. (a cura di). Riflessioni: l'arte del disegno/il disegno dell'arte / Reflections: the art of drawing/the drawing of art. Atti del $41^{\circ}$ Convegno internazionale dei Docenti delle discipline della Rappresentazione / Proceedings of the 4 I $^{\text {th }}$ International Conference of Teachers of the disciplines of the Representation, pp. 817-824. Roma: Gangemi Editore.

Paris L. (20|4). Dal problema inverso della prospettiva al raddrizzamento fotografico. Roma: Aracne Editrice.

Russo M., Guidi G. (20I I). Reality-based and reconstructive models: digital media for cultural heritage valorization. In SCIRES vol. I, issue 2, pp. 7 I-86.

Sanna L., Ursini E. (20 I5). II contributo del rilievo digitale al restauro della Porta del Paradiso. In Giusti A. (a cura di.). II Paradiso ritrovato. II restauro della Porta del Ghiberti, pp. 2 19-225. Firenze: Mandragore.

Siano S. (20 I5). La lettura materica della Porta del Paradiso. In Giusti A. (a cura di.). II Paradiso ritrovato. II restauro della Porta del Ghiberti, pp. 67-80. Firenze: Mandragore.

\section{Authors}

Alessandro Merlo, Università degli Studi di Firenze, alessandro.merlo@unifi.it

Matteo Bartoli, Università degli Studi di Firenze, matteo.bartoli@unifi.it

To cite this chapter. Merlo Alessandro, Bartoli Matteo (202I). Modelli interpretativi a servizio dell'arte: la porta del paradiso di Lorenzo Ghiberti/Interpretative Models Employed by Art: the Gates of Paradise by Lorenzo Ghiberti. In Arena A., Arena M., Mediati D. Raffa P. (a cura di). Connettere. Un disegno per annodare e tessere Linguagoi Distanze Tecnologie. Atti del $42^{\circ}$ Convegno Internazionale dei Docenti delle Discipline della Rappresentazione/Connecting. Representation Disciplines Teachers. Milano: FrancoAngeli, pp. 2493-25I2. 